\title{
Hastelloy C-276Weld Overlay bySMAW Process
}

\author{
Er. Rahul Sharma ${ }^{1}$ Er. Manoj Kumar ${ }^{2}$, Dr. Abhishek Kamboj ${ }^{3}$ \\ $1 \mathrm{M}$. tech research Scholar, Haryana Engineering College \\ 2 Tech advisor, ISGEC Heavy Engineering \\ 3 Associate Professor, Haryana Engineering College
}

\begin{abstract}
In the modern world of industrialization the wear is eating metal assets worth millions of dollars per year. The wear is in the form of corrosion, erosion, abrasion etc. which occur in the process industries like oil \& gas, refineries, cement plants, steel plants, shipping and offshore working structures. The equipments like pressure vessels, heat exchangers, hydro processing reactors which very often work at elevated temperatures face corrosion in the internal diameter.Hastelloy C-276weld overlay on ferrous material is developed for outstanding resistance to wide variety of chemical process environments such as ferric and cupric chlorides, hot contaminated mineral acids, solvents, chlorine and chlorine contained media, both inorganic and organic, dry chlorine, formic and acetic acids, acetic anhydride, sea water and brine solutions.Selection of SMAW is for development of hastalloy C-276 material with SMAW process to use as a weld overlay process at non accessible area $\&$ where position is constraint which is not feasible by other processes like ESSC, FCAW, and SAW etc.
\end{abstract}

\section{INTRODUCTION}

Hastelloy C-276 is family part of Nickel alloy. Nickel in elemental form or alloyed with other metals and materials has made significant contributions to our present-day society and promises to continue to supply materials for an even more demanding future. Nickel is a versatile element and will alloy with most metals. Complete solid solubility exists between nickel and copper. Wide solubility ranges between iron, chromium, and nickel make possible many alloy combinations. VariousType of nickel alloy:

-Inconel alloy

-Monel alloy

-Hastelloy alloy.

Inconel is a family of austenite nickel-chromiumbased super alloys.

Inconel alloys are oxidation and corrosion resistant materials well suited for service in extreme environments subjected to pressure and heat. When heated, Inconel forms a thick, stable, passivating oxide layer protecting the surface from further attack. Inconel retains strength over a wide temperature range, attractive for high temperature applications where aluminum and steel would succumb to creeps a result of thermally induced crystal vacancies. Inconel's high temperature strength is developed by solid solution strengthening orprecipitation hardening, depending on the alloy.

\subsection{Hastelloy C-276}

Hastelloy C-276 is a nickel-molybdenumchromium-tungsten alloy with excellent general corrosion resistance and good fabricability. The alloy should be considered for use in environments where resistance to hot contaminated mineral acids, organic and inorganic chloride-contaminated media, chlorine, formic and acetic acids, acetic, acetic anhydride, sea water and brine solutions is desired.Hastelloy C-276 has resisted the formation of grain boundary precipitates in the weld heataffected zone, making it a candidate for most chemical and petrochemical processing applications in the as-welded condition. The alloy has resisted both general and localized corrosion, including pitting, crevice corrosion, and stress corrosion cracking.

Hastelloy C-276 is readily fabricated by welding, using methods similar to those utilized for nickel-based alloys.

Hastelloy C-276 generally have good weldability and can be welded using most of the welding methods used for Hastelloy C-276:

- Shielded metal arc welding (SMAW)

- Gas tungsten arc welding TIG (GTAW)

- Gas metal arc welding MIG (GMAW)

1.2 Characteristics of Hastelloy C- 276

- Excellent resistance to stress corrosion cracking

- Very high mechanical strength

- Excellent resistance to pitting and crevice corrosion

- High resistance to general corrosion in a variety of environments

- High resistance to erosion corrosion and corrosion fatigue

- Good weldability

- Lower life cycle cost 
1.3 Chemical Composition of Hastelloy C- 276

\begin{tabular}{|l|l|}
\hline Elements & Percentage \\
\hline Nickel & Balance \\
\hline Molybdenum & $15.0-17.0$ \\
\hline Chromium & $14.5-16.5$ \\
\hline Iron & $4.0-7.0$ \\
\hline Tungsten & $3.0-4.5$ \\
\hline Cobalt & 2.5 max. \\
\hline Manganese & 1.0 max. \\
\hline Carbon & 0.01 max. \\
\hline Vanadium & 0.35 max. \\
\hline Phosphorus & 0.04 max. \\
\hline Sulfur & 0.03 max. \\
\hline Silicon & 0.08 max \\
\hline
\end{tabular}

Table 1

Cladding is a welding process in which a material with desired properties is deposited on the surface of a base material. The common C/Mn or low alloyed inexpensive base metal has mainly a load carrying function. The deposited sophisticated material imparts surface properties such as corrosion resistance; wear resistance, erosion and pitting etc., to the substrate. To the manufacturer of pressure vessels, surfacing techniques are getting more and more important. Components reach sizes such that their fabrication calls upon the use of clad materials.

There are different processes to obtain a clad material:

- Clad plates produced by rolling which are mostly only available in standardized dimensions and grades

- Explosion clad plates

- Clad plates made by welding

Further Clad Plates made by welding can be done using various techniques:-

- $\quad$ Submerged arc welding (Wire electrode)

- Submerged arc welding (Twin Wire electrode)

- $\quad$ Submerged arc welding (Strip Electrode)

- Electro slag strip welding

- $\quad$ Shielded metal arc welding

- Flux cored arc welding

The shielded metal arc welding process is well known for its versatility because it can be used in all welding positions, and in both production and repair situations. It is generally not useful on thin sheet material. It requires no special equipment and can be operated easily in remote locations. It is strictly a manual welding process.

\section{PROCESS DESCRIPTION}

Shielded metal arc welding (SMAW), also known as manual metal arc welding (MMA or MMAW), flux shielded arc welding or informally as stick welding, is a manual arc welding process that uses a consumable electrode covered with a flux to lay the weld.An electric current, in the form of either alternating current or direct current from a welding power supply, is used to form an electric arc between the electrode and the metals to be joined. The work piece and the electrode melt forming a pool of molten metal (weld pool) that cools to form a joint. As the weld is laid, the flux coating of the electrode disintegrates, giving off vapors that serve as a shielding gas and providing a layer of slag, both of which protect the weld area from atmospheric contamination.

Operation

To strike the electric arc, the electrode is brought into contact with the work piece by a very light touch with the electrode to the base metal then is pulled back slightly. This initiates the arc and thus the melting of the work piece and the consumable electrode, and causes droplets of the electrode to be passed from the electrode to the weld pool.

Striking an arc, which varies widely based upon electrode and workpiece composition, can be the hardest skill for beginners. The orientation of the electrode to workpiece is where most stumble, if the electrode is held at a perpendicular angle to the workpiece the tip will likely stick to the metal which will fuse the electrode to the workpiece which will cause it to heat up very rapidly. The tip of the electrode needs to be at a lower angle to the workpiece, which allows the weld pool to flow out of the arc. As the electrode melts, the flux covering disintegrates, giving off shielding gases that protect the weld area from oxygen and other atmospheric gases.

In addition, the flux provides molten slag which covers the filler metal as it travels from the electrode to the weld pool. Once part of the weld pool, the slag floats to the surface and protects the weld from contamination as it solidifies. Once hardened, it must be chipped away to reveal the finished weld. As welding progresses and the 
electrode melts, the welder must periodically stop welding to remove the remaining electrode stub and insert a new electrode into the electrode holder. This activity, combined with chipping away the slag, reduces the amount of time that the welder can spend laying the weld, making SMAW one of the least efficient welding processes. In general, the operator factor, or the percentage of operator's time spent laying weld, is approximately $25 \%$

The actual welding technique utilized depends on the electrode, the composition of the workpiece, and the position of the joint being welded. The choice of electrode and welding position also determine the welding speed. Flat welds require the least operator skill, and can be done with electrodes that melt quickly but solidify slowly. This permits higher welding speeds.

Sloped, vertical or upside-down welding requires more operator skill, and often necessitates the use of an electrode that solidifies quickly to prevent the molten metal from flowing out of the weld pool. However, this generally means that the electrode melts less quickly, thus increasing the time required to lay the weld.

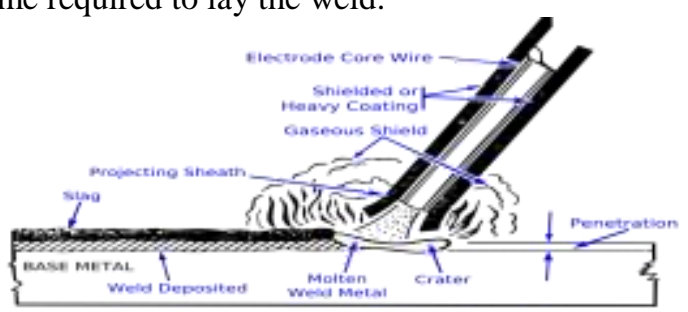

Fig.1

\section{EXPERIMENTATION AND TESTING :}

Discuss the detail about the experimental data, base metal, filler metal, and welding procedure, welding parameters of welded specimen and testing.

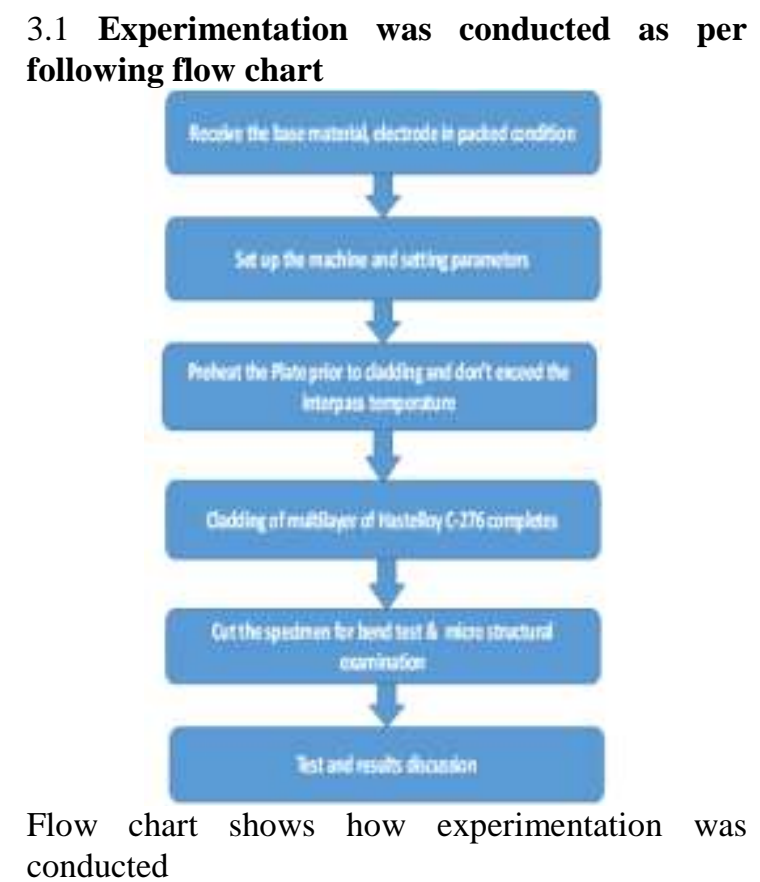
conducted

\subsection{Base Metal and Electrode}

The base plate of low carbon steel -SA 516 Grade 70 of thickness $30 \mathrm{~mm}$ received in normalized heat treated condition. The electrode used were of ENiCrMo-4 as a barrier as well as clad layer. Table 3.1 shows the chemical composition of base metal \&electrode.

\begin{tabular}{|l|l|l|}
\hline Elements (Wt.\%) & Base Metal & HASTELLOY-ENICrMO-4 \\
\hline Carbon, C & 0.27 & 0.02 \\
\hline Silicon, Si & $0.15-0.40$ & 0.2 \\
\hline Sulfur, S & 0.035 & 0.03 \\
\hline Phosphorous, P & 0.035 & 0.04 \\
\hline Manganese & $0.85-1.20$ & 1.0 \\
\hline Chromium & - & $14.5-16.5$ \\
\hline Nickel & - & Remainder \\
\hline Molybdenum & - & $15-17$ \\
\hline
\end{tabular}

\section{Table 2}

\subsection{Welding Parameters}

Material

Heat treatment

Plate size

Electrode for Barrier-(ENiCrMo-4)

Electrode for Clad(ENiCrMo-4)

Weld Bead Height:6 mm- Multiple Layer
:- $\quad$ SA 516 Grade 70 (low carbon steel)

:- $\quad$ Normalized condition.

:- $\quad 300$ X 300 X 30 mm thick

:- $\quad 2.5 \mathrm{dia}$

:- $\quad 3.2 \mathrm{~mm} \mathrm{dia}$ 


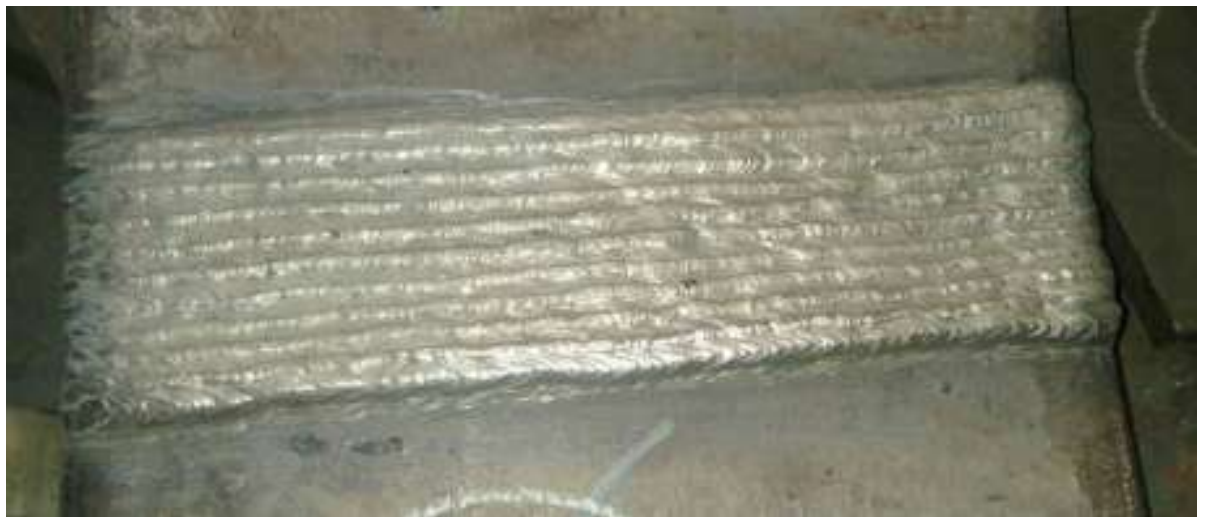

Fig.2

\begin{tabular}{|l|l|}
\hline Parameters & Range \\
\hline Welding current (I) & $80-130$ Amp \\
\hline Voltage (V) & $22-28 \mathrm{~V}$ \\
\hline Travel Speed & $220-250 \mathrm{~mm} / \mathrm{min}$ \\
\hline Pre heat & 75 degree Celsius \\
\hline Interpass & Max 200 \\
\hline Polarity & DCEP \\
\hline
\end{tabular}

Table 3

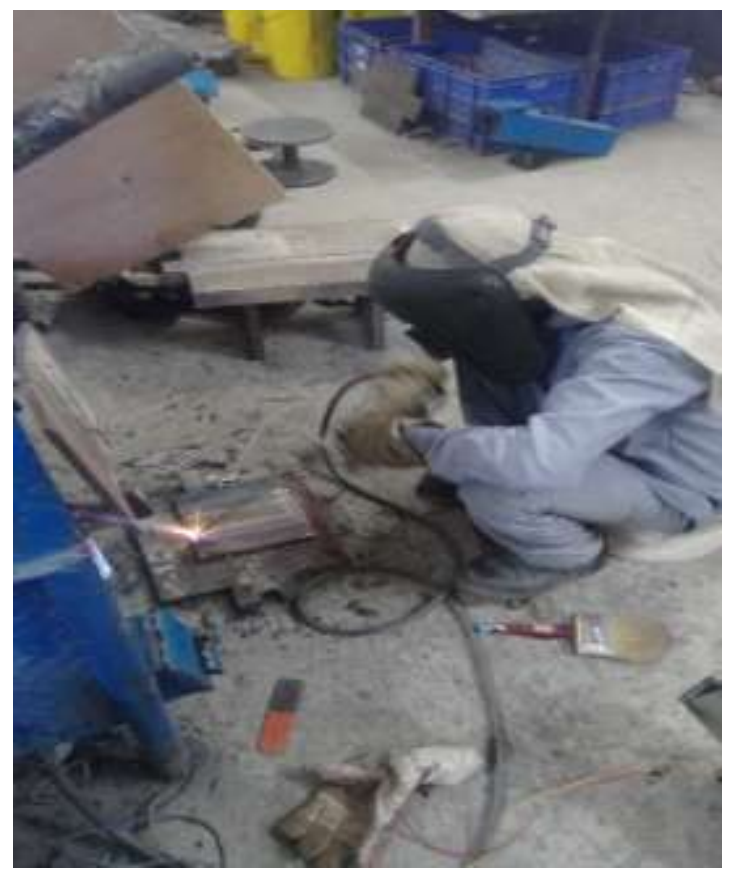

Fig.3

3.4 Post Weld Heat Treatment (PWHT)

PWHT was performed at $610-620^{\circ} \mathrm{C}$ for 135 minutes after completion of testing with heating rate $50^{\circ} \mathrm{C} / \mathrm{hr}$ and cooling rate $40^{\circ} \mathrm{C} / \mathrm{hr}$.

\section{RESULTS}

$>$ Non Destructive Testing :-

$\checkmark$ Visual Examination :

○ Bead Finish : Good

$\circ$ Weld Fusion : Good 
○ Slag Inclusion $\quad: \quad$ No

○ Undercut : No

$\circ$ Crater porosity \& Crack : $\quad$ No

$\checkmark$ Dye Penetrant Testing : Acceptable as per ASME Sec IX .

$\checkmark$ Ultrasonic Examination : Satisfactory

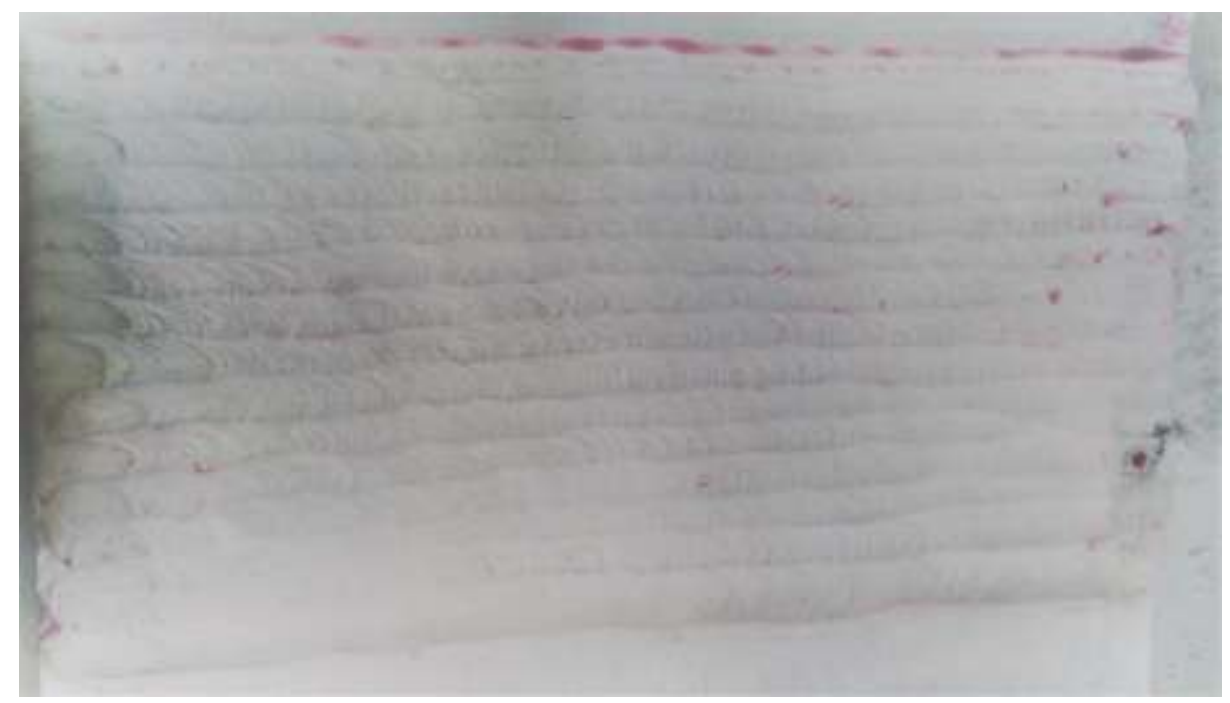

Fig.4

$\checkmark$ Macro Examination : Noporosity, No Lack of Fusion \&complete fusion of weld metal \& base metal BendTest:satisfactory

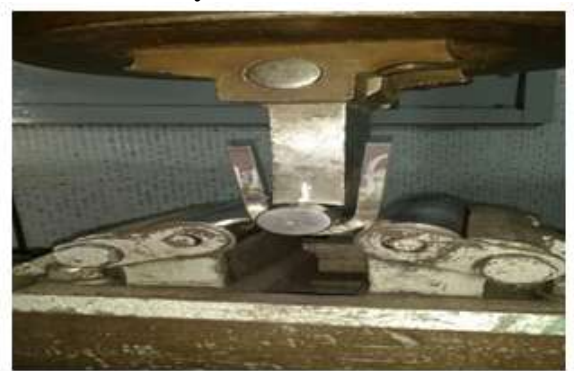

Fig.5

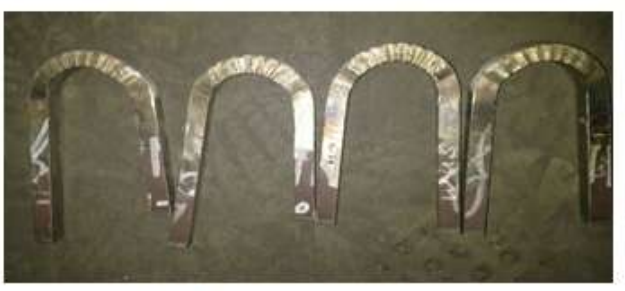

Fig.7

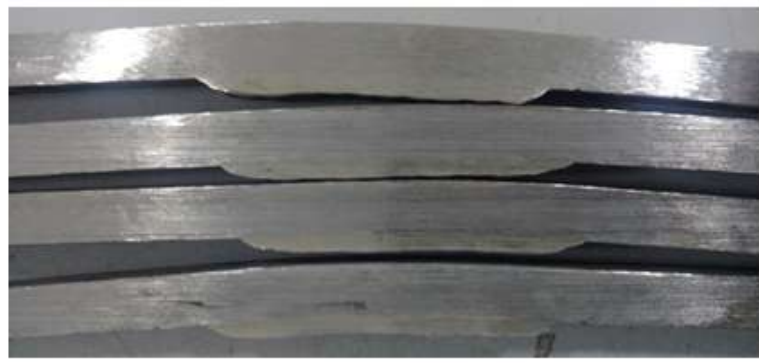

Fig. 6

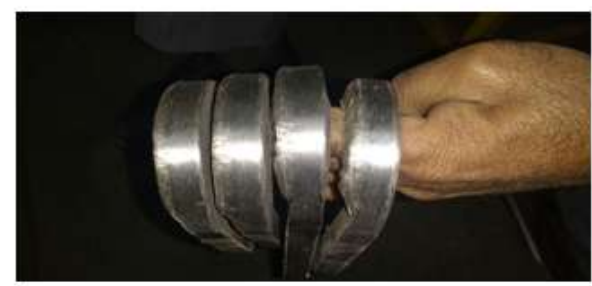

Fig.8

\begin{tabular}{|c|c|c|c|c|}
\hline $\begin{array}{c}\text { Test } \\
\text { Performed }\end{array}$ & $\begin{array}{c}\text { Number of } \\
\text { Sample Tested }\end{array}$ & $\begin{array}{c}\text { Degree of } \\
\text { 4Bend }\end{array}$ & $\begin{array}{c}\text { Acceptance } \\
\text { Standard }\end{array}$ & Results \\
\hline $\begin{array}{c}\text { Side Bend } \\
\text { Test }\end{array}$ & 4 & $180^{\circ}$ & ASME Sec IX & Satisfactory \\
\hline
\end{tabular}


ChemicalComposition was found satisfactory from $2.5 \mathrm{~mm}$ fusion line

\begin{tabular}{|c|c|c|c|c|c|c|c|c|}
\hline \multirow{2}{*}{$\begin{array}{c}\text { Height } \\
(\mathbf{m m})\end{array}$} & \multicolumn{9}{|c|}{ \% Element } \\
\cline { 2 - 9 } & $\mathrm{C}$ & $\mathrm{Si}$ & $\mathrm{S}$ & $\mathrm{P}$ & $\mathrm{Mn}$ & $\mathrm{Ni}$ & $\mathrm{Cr}$ & Mo \\
\hline $\begin{array}{c}\text { Reqd } \\
\text { value }\end{array}$ & $\mathbf{0 . 0 2}$ & $\mathbf{0 . 2} \mathbf{~ m a x}$ & $\mathbf{0 . 0 3}$ & $\mathbf{0 . 0 3 5}$ & $\mathbf{1 . 0} \mathbf{m a x}$ & $\begin{array}{c}\text { Remain } \\
\text { max }\end{array}$ & $\begin{array}{c}14.5- \\
16.5\end{array}$ & $15-17$ \\
\hline 4.0 & 0.020 & 0.16 & 0.003 & 0.006 & 0.30 & 56.64 & 15.55 & 15.42 \\
\hline 3.5 & 0.020 & 0.15 & 0.002 & 0.006 & 0.31 & 56.29 & 15.54 & 15.38 \\
\hline 3.0 & 0.020 & 0.15 & 0.003 & 0.006 & 0.31 & 55.71 & 15.88 & 15.30 \\
\hline 2.5 & 0.020 & 0.16 & 0.003 & 0.006 & 0.31 & 56.28 & 15.0 & 15.40 \\
\hline 2.0 & 0.028 & 0.16 & 0.003 & 0.007 & 0.35 & 53.31 & 14.16 & 14.52 \\
\hline 1.5 & 0.028 & 0.16 & 0.003 & 0.006 & 0.35 & 52.78 & 13.94 & 13.41 \\
\hline 1.0 & 0.034 & 0.17 & 0.003 & 0.006 & 0.38 & 51.22 & 13.16 & 13.99 \\
\hline
\end{tabular}

\section{$\checkmark$ CORROSION TESTING AS PER ASTM G28 METHOD B}

Result observed:

Initial weight of specimen: $10.9212 \mathrm{~g}$

Weight after 24 hours $\quad: 10.8545 \mathrm{~g}$

Weight loss : $0.0667 \mathrm{~g}(0.70 \mathrm{mg})$

$\checkmark$ CORROSION TESTING AS PER ASTMG48 METHOD B

Result observed:

Testing results at temperature $50^{\circ} \mathrm{C}$

Initial weight of specimen $: 33.5063 \mathrm{~g}$

Weight after 24 hours $\quad: 33.5048 \mathrm{~g}$

Weight loss (g) : 0.0015

Weight loss (mg) : 1.50

No Crevice crack observed on the surface at $20 \mathrm{X}$

Magnification.

\section{CONCLUSION}

Typical to weld HastelloyC-276 welded successfully meeting the requirement of ASME Sec IX \& Sec IIC.

\section{Scope of Future Work}

As a future work, we will establish corrosion test as per customer requirement such as ASTM G-48 method A-pitting corrosion ASTM G-36 etc.

\section{REFERENCES}

[1]. E. M. Sherif , " Corrosion of Duplex Stainless Steel Alloy 2209 in Acidic and Neutral Chloride solutions and its passivation by Ruthenium as an alloying element."International journal of electrochemical Science 7 (2012)

[2]. S. D. Kahar ," Corrosion Behavior of Electro Slag Strip Cladding Weld Overlays in Different Acid Solutions ", Int. Journal of Engineering Research and applications Vol. 3, Issue 4,july-aug 2013 pp.590-595, 2012

[3]. M. Patel," Application of Electro Slag Strip Cladding for reactors in Hydrogen Based Refinery"2009-IIW india
[4]. A.Eghlimi "dilution and ferrite number prediction in pulsed current cladding of super duplex stainless steel using RSM" ASM international (2013).

[5]. T. Kannan: "effect of flux cored arc welding process parameters on duplex stainless steel clad quality". Journal of materials processing technology 176(2006).

[6]. R.A Daemen: submerged arc stainless steel strip cladding: the development of welding products for surfacing with a type of $316 \mathrm{~L}$ low ferrite stainless steel alloy. Welding Research supplement January-1970.

[7]. S.Pak "Electro slag and Submerged Arc stainless steel strip cladding."published by ESAB in Svetsaren No.3,1996

[8]. J. Garg, "reuse of slag in stainless steel cladding and its effect on chemistry of cladding in SAW process "Journal of Environmental research \& Development(March 2012).

[9]. Cary, Howard B.; Helzer, Scott C. (2005), Modern Welding Technology, Upper Saddle River, New Jersey: Pearson Education. 